\title{
Students' Creativity in Matlab Programming as Media in Learning Mathematics
}

\author{
Octavina Rizky Utami Putri \\ Program Study of Mathematics Education \\ University of Muhammadiyah Malang, Indonesia \\ octavina@umm.ac.id
}

\begin{abstract}
The purpose of this research is to describe the process and product of student creativity in programming Matlab as the base of making of learning media of mathematics based on Information and Technology (IT). This research is a qualitative descriptive research. The data collection technique employed by using assignment and interview. This assignment is analyzed by using an analytic rubric. All data are analyzed by reducing data, presenting data, and drawing conclusions. Students' creativity processes include synthesizing, building, and applying ideas. Students synthesize ideas by connecting mathematical material with Matlab programming material, as well as connecting Matlab programming material. Students build ideas by creating a learning media design through a flowchart. Students apply the idea by writing the script Matlab programming based on the flowchart that has been made. Learning media products contain originality, that is, there is a logic of 'while' repetition on the terms of selecting the menu. The program is stopped if the wrong menu is entered incorrectly three times.
\end{abstract}

Keywords - creativity process, creativity product, programming, matlab

\section{INTRODUCTION}

Creativity is closely related to real life issues [1], [2], [3]. This is relevant to [4]'s statement that creativity is needed to solve problems especially real problems. In addition, creativity can provide evidence of success in learning [5], [6]. Creativity is the ability to provide new ideas that can be applied in solving problems, or as the ability to see new relationships between elements that already existed [7], [8], [9]. Viewed as a process, creativity involves synthesizing, building, and implementing ideas in solving problems. Synthesizing the idea means linking a given problem with the knowledge the student has. Building ideas means generating solutions related to given problems. Implementing ideas means implementing ideas to solve problems [10]. The definition of creativity products emphasizes that what results from the creative process is something new, original, and meaningful. Creativity products are embodied in three characteristics, namely: fluency, flexibility and originality [3]. [7] explains that the novelty in creativity products is not something that should not exist before, but must be considered from the point of view of the creator. The real problem can be solved with the help of IT [11]. Related to that, [12] in their research mentioned that lecturers are required to be able to bring out creative students who can create solutions to solve real life problems through the ability of IT and mathematics.
Mathematics Education Study Program University of Muhammadiyah Malang provides IT development facility through computing course, one of them is "Language Programming". In this course, students are equipped to master programming using Matlab. Outline of this course is the student can make an IT-based mathematics learning media using Matlab.

Matlab (Matrix Laboratory) is an application for processing numerical data as well as programming languages with basic element arrays to run engineering and mathematical calculations [13], [14]. In Matlab there is an m-file feature that serves to write the script [13]. This script is based on creativity in making the program as a medium of learning mathematics. The purpose of this study is to describe the process and product creativity of students in programming using Matlab as the basis for making learning media of mathematics based on Information and Technology (IT).

\section{RESEARCH METHOD}

The type of this research is descriptive with qualitative approach. This research involves students of Mathematics Education Study Program University of Muhammadiyah Malang which is taking the program of Pemrogaman Language as the subject. The researcher gave the task of making mathematics learning media using Matlab program. Each student is given freedom in determining mathematical material. Analytical and interviewing rubrics are used to derive process data and creativity products. Indicators of the creativity process include synthesizing, building, and applying ideas, while creativity products contain indicators of originality. All data were analyzed by reducing the data, presenting the data, and drawing conclusions.

\section{RESUlt AND DisCUSSION}

\section{A. Creativity Process}

Students can synthesize ideas in making media using Matlab program, meaning they can relate mathematical material with Matlab programmer material, as well as between Matlab programming material. Learning media made by students include material Geometry Shape 3D, Sequence and Series, Trigonometry, Linear Equation System, Statistics, Graph Drawing, and so forth. Students associate mathematical operations with arithmetic, relational, and logical operators on learning programming using Matlab. The linkage of 
mathematical operations with arithmetic, relational, and logic operators is described in the following table.

TABLE I. RELATIONS BETWEEN MATHEMATICS OPERATION AND OPERATOR IN MATLAB

\begin{tabular}{|c|c|c|}
\hline \multirow{6}{*}{$\begin{array}{c}\text { Arithmetic } \\
\text { Operator }\end{array}$} & $\begin{array}{l}\text { Matlab } \\
\text { Operator }\end{array}$ & Notes \\
\hline & + & Additions \\
\hline & - & Reductions \\
\hline & 1 & Divisons \\
\hline & $*$ & Multiplication \\
\hline & $\wedge$ & Rank \\
\hline \multirow{6}{*}{$\begin{array}{l}\text { Relational } \\
\text { Operator }\end{array}$} & $==$ & Equal to \\
\hline & $\sim=$ & Not equal to \\
\hline & $<$ & Less than \\
\hline & $<=$ & Less than or equal to \\
\hline & $>$ & More than \\
\hline & $>=$ & More than or equal to \\
\hline \multirow{2}{*}{$\begin{array}{c}\text { Logical } \\
\text { Operator }\end{array}$} & $\&$ & And \\
\hline & & Or \\
\hline
\end{tabular}

In addition to the above table, students associate the basic logic of mathematics with Matlab programming, such as the conjunction using " $\&$ " in Matlab, disjunction using "|" on Matlab, and the implications of using "if ... else ... end" or "if ... elseif ... else ... end" or "switch ... case ... end" on Matlab. Students also associate sequence and series material by using "while" and "for". Mathematics learning media made by students vary. Students also associate between Matlab programming material that is "switch", "if", "while", or for on the program created. It is intended that the media created in accordance with the solution of mathematical problems that the programmer wants.

Students build ideas by creating a flowchart. This flowchart is designed to create Matlab program. Flowcharts made by diverse students. This flowchart consists of symbol "terminator", "flow line", "input / output data", "process", "decision", "on page connector", "off page connector", and "subprogram". In building this idea, students are creative in designing Matlab program. Students create a flowchart with a beginning and end terminator. Here is an example of some of the flowcharts made by students.

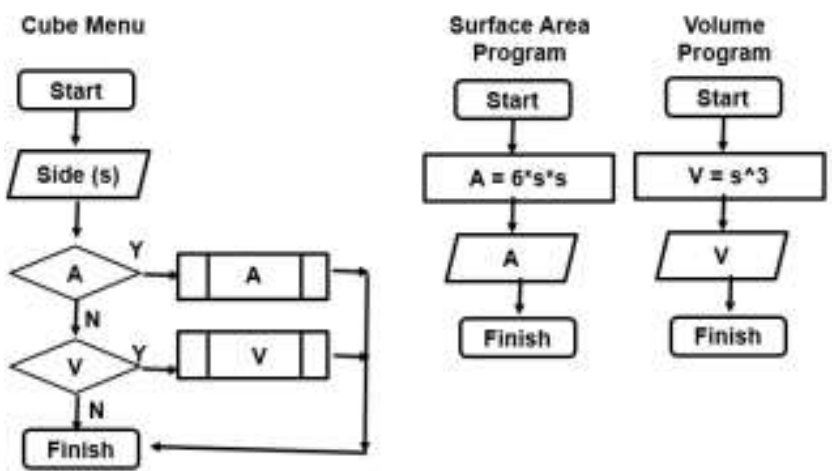

Fig 1. Sample of student's flowchart

Planning the program created by the students above is to create the Cube program. The flowchart explains that (1) the program requires side "input", (2) the user is asked to choose the process of surface area or volume, (3) the area and volume are processed on a separate sub program. Sub program aims to simplify the created program.

Students apply the idea by writing program script on m-file. The script is written based on the student's flowchart. For example, students give a command switch to program menu options. There are two types of "switch" program made by students, which involves input with numerical and string data types. Differences in input of numeric and string data types are in "input" and "case" scripts as follows.

TABLE II. DifFERENCES BETWEen SWITCH COMMAND SCRIPTS USING NUMERICAL AND STRINGS DATA TYPES

\begin{tabular}{cc}
\hline \multicolumn{1}{c}{ Numerik } & String \\
\hline $\mathrm{n}=$ input ('String: '); & $\mathrm{n}=$ input ('String: ','s'); \\
switch n & switch n \\
case numerical & case 'string' \\
disp('Output') & disp('Output') \\
case numerical & case 'string' \\
disp('Output') & disp('Output') \\
$\ldots$ & $\ldots$ \\
otherwise & otherwise \\
disp('Output') & disp('Output') \\
end & end \\
\hline
\end{tabular}

Differences in the use of numerical and string inputs in the table above are tailored to the wishes of programmers (students) in designing the program. This is useful to give the user easiness in using student learning media.

Based on the results of the analysis, there is a difference between the flowchart that has been designed with the program created by students. This is because the student has a change of idea when writing the program script, thus the program created does not match the initial design on the flowchart. For example in the cube program. The flowchart in figure 1 does not match the student program. Students give additional terms on the input side, i.e. the side is more than zero. The idea of changing this is very good because the side length requirement is must be more than zero. In addition to the cube, the students also provide a long, wide, and high input requirement on the beam. This third requirement must be more than zero. If the conditions "if $(\mathrm{p}>0) \&(\mathrm{l}>0) \&(\mathrm{t}>0)$ " are met, then it is instructed to process the square prism surface area of "area $=2$ $*((p * 1)+(p * t)+(1 * t)) ;$;. If it does not meet all three then the surface area of the square prism cannot be processed.

The result of the application of this idea found the originality of mathematics learning media products. This originality lies in the repetition outside the mathematics course. Students use the logical repetition to run the program. If there are three times mistakes chronologically when entering the menu, the program will be stopped. This is different from the results of research [10] which states that originality appears in the idea of building. This is because students change the initial idea on the flowchart into script writing on the program. Therefore, originality arises when applying ideas.

\section{B. Creativity Product}

The learning media made by the students varies, which includes the material of Geometry Shape 3D, Sequence and Series, Trigonometry, Linear Equation System, Statistics, Graph Drawing, and so forth. Display of these media in general 
displays the menu options, submenu, input, process, output. There is an interesting on the outcomes of learning media made by students. There is one program that is unique, original, and different from other students. The name of the program is Geometry Shape 3D Program. The student gives a while repetition command to provide a condition for choosing the correct Geometry Shape 3D. The program runs the command if the option of Geometry Shape 3D entered is correct. The program will be stopped if three times in a row made a mistake selecting Geometry Shape 3D. Below is an original screenshot of the original Geometry Shape 3D program script.

chance $=1$;

while chance $<3$

$\mathrm{n}=$ input ('Enter your choice: ','s');

switch $n$

case 'cube'

disp ('Your choice is cube')

...

chance $=0$;

case 'square prism'

disp ('Your choice is square prism')

...

chance $=0$

...

\section{otherwise}

disp ('Watch Instructions!')

chance $=$ chance +1 ;

end

The explanation of the script above is (1) the input of your choice, (2) if the choice is correct then the process is continued, (3) if the wrong choice is given the output "Watch Instructions", if wrong done back then

opportunity_1 $=1$

occasion_2 = chance_ $1+1=1+1=2$

occasion_3 $=$ chance $22+1=2+1=3$

occasion_4 $=$ chance_3 $+1=3+1=4$

occasion 4 is worth 4 then the program stops because there is a "while opportunity <3" condition. Therefore, the program is stopped when the wrong opportunity is done the fourth repetition.

\section{CONCLUSION}

Student's creativity process involves synthesizing, building, and applying ideas. Students synthesize the idea of instructional media by linking mathematical material with Matlab programming or interlacing Matlab programming. Students build instructional media ideas by designing Matlab program through flowchart. Students apply the idea of learning media by writing script program of Matlab based on flowchart made. In the creativity product there is a difference with the flowchart that has been made. This is because students get other ideas when writing scripts. There is originality in the product of student learning media. Students use repetition logic to provide a condition for running the program. The program was terminated when the user entered the menu incorrectly 3 times in a row.

\section{REFERENCES}

[1] Y. Wang and V. Chiew. "On the Cognitive Process of Human Problem Solving”, Cognitive Systems Research: An International Journal. vol. 11, pp. 81-92, 2010

[2] A. Bahar and C. Maker. "Exploring the Relationship between Mathematical Creativity and Mathematical Achievement", Journal of Gifted and Talented Education. vol. 3, pp. 33-48, 2011.

[3] H. Wessels. "Levels of Mathematical Creativity in Model-Eliciting Activities", Journal of Mathematical Modelling and Application. vol. 1, pp. 22-40, 2014.

[4] Subanji, "Pembelajaran Matematika Kreatif dan Inovatif". Malang: Universitas Negeri Malang, 2013.

[5] G. Williams. "Classroom Teaching Experiment: Eliciting Creative Mathematical Thinking", Journal for the Psychology of Mathematics Education. vol. 4, pp. 257-264, 2007.

[6] Y. Attali and D. Powers. "Immediate Feedback and Opportunity to Revise Answers to Open-Ended Questions", Educational and Psychological Measurement. vol. 70, pp. 22-35, 2010.

[7] U. Munandar, "Pengembangan Kreativitas Anak Berbakat". Jakarta: Rineka Cipta, 2009.

[8] T.Y.E. Siswono. "Level of Student's Creative Thinking in Classroom Mathematics", Academic Journal. vol. 6, pp. 548-553, 2011.

[9] Y. Wang. "On Cognitive Foundations of Creativity and The Cognitive Process of Creation", International Journal of Cognitive Informatics and Natural Intelligence. vol 3, pp.1-18, 2009.

[10] T.Y.E. Siswono. "Proses Berpikir Kreatif Siswa dalam Memecahan dan Mengajukan Masalah Matematika”, Jurnal Ilmu Pendidikan. vol. 15, pp. 60-68, 2008.

[11] S. Mithas and R. T. Rust. "How Information Technology Strategy and Investments Influence Firm Performance: Conjecture and Empirical Evidence", Scholary Journal. vol. 40, pp. 223-245, 2016.

[12] J.A. Hartono and I. Karnasih, "Pentingnya Pemodelan Matematis dalam Pembelajaran Matematika" in Seminar Nasional Matematika: Peran Alumni dalam Membangun Jejaring Kerja dan Peningkatan Kualitas Pendidikan, Medan, 2017.

[13] B.D. Hahn and D. T. Valentine, "Essential Matlab for Engineers and Scientists". Oxford: Elsevier Ltd, 2007.

[14] K. Ogata, "Matlab for Control Engineers". London: Pearson Education, Inc, 2008. 